University of Nebraska - Lincoln

DigitalCommons@University of Nebraska - Lincoln

Agronomy \& Horticulture -- Faculty Publications

Agronomy and Horticulture Department

2002

\title{
Crop Sequence and Nitrogen Fertilization Effects on Soil Properties in the Western Corn Belt
}

\author{
M. A. Liebig \\ USDA-ARS
}

Gary E. Varvel

University of Nebraska-Lincoln, gevarvel@windstream.net

John W. Doran

University of Nebraska-Lincoln, jdoran1@unl.edu

Brian J. Wienhold

University of Nebraska-Lincoln, Brian.Wienhold@ars.usda.gov

Follow this and additional works at: https://digitalcommons.unl.edu/agronomyfacpub

Part of the Plant Sciences Commons

Liebig, M. A.; Varvel, Gary E.; Doran, John W.; and Wienhold, Brian J., "Crop Sequence and Nitrogen Fertilization Effects on Soil Properties in the Western Corn Belt" (2002). Agronomy \& Horticulture -Faculty Publications. 330.

https://digitalcommons.unl.edu/agronomyfacpub/330

This Article is brought to you for free and open access by the Agronomy and Horticulture Department at DigitalCommons@University of Nebraska - Lincoln. It has been accepted for inclusion in Agronomy \& Horticulture -Faculty Publications by an authorized administrator of DigitalCommons@University of Nebraska - Lincoln. 


\title{
Crop Sequence and Nitrogen Fertilization Effects on Soil Properties in the Western Corn Belt
}

\author{
M. A. Liebig,* G. E. Varvel, J. W. Doran, and B. J. Wienhold
}

\begin{abstract}
Understanding long-term management effects on soil properties is necessary to determine the relative sustainability of cropping systems. Soil physical, chemical, and biological properties were measured in a long-term cropping system study in the Western Corn Belt. Properties were evaluated after $16 \mathrm{yr}$ in four crop sequences [continuous corn (zea mays L.) (CC), corn-soybean [Glycine max. (L.)] (C-SB), corn-oat (Avena sativa $\mathbf{L}$.) + clover $(80 \%$ sweet clover [Melilotus officinalis L.] and $20 \%$ red clover [Trifolium pratense $\mathrm{L}$. ])-grain sorghum [(Sorghum bicolor (L.) Moench)-soybean (C-OCL-SGSB), and corn-soybean-grain sorghum-oat + clover (C-SB-SGOCL)] each at three $\mathbf{N}$ fertilization rates (ZERO, LOW, and HIGH) to a soil depth of $30.5 \mathrm{~cm}$ on a Sharpsburg silty clay loam (fine, smectitic, mesic Typic Argiudolls). Nitrogen fertilization had a greater impact on soil properties than crop sequence, with management effects most pronounced at 0 to $7.6 \mathrm{~cm}$. Increased $\mathrm{N}$ rate resulted in greater organic C, total $\mathrm{N}$, and particulate organic matter (POM), but lower soil $\mathbf{p H}$. Increased $\mathrm{N}$ rate also reduced microbial biomass by $\sim 20 \%$ between the HIGH and ZERO N-rate treatments. The C-SB-SGOCL sequence possessed more potentially mineralizable N (PMN) ( $57 \mathrm{vs.} 46 \mathrm{~kg} \mathrm{ha}^{-1}$ for average of $\mathrm{CC}$ and $\left.\mathrm{C}-\mathrm{SB}\right)$ and a higher percentage of POM present as soil organic matter (17.1\% for the C-SB-SG-OCL sequence vs. $13.9 \%$ for other sequences). Within the context of soil functions and cropping system performance, results from this study indicate the C-SB-SB-OCL sequence enhanced nutrient cycling efficiency, while $\mathbf{N}$ fertilization resulted in a trade-off between its positive effect on biological productivity and negative effect on nutrient cycling efficiency.
\end{abstract}

$\mathrm{T}_{\mathrm{i}}$ HE LONG-TERM SUSTAINABILITY of cropping systems is largely determined by their impact on soil quality. Because soil quality is directly related to the capacity of soil to function (Karlen et al., 1997), it envelops many aspects of cropping system performance. Measures of performance include biological productivity, erosion resistance, nutrient cycling efficiency, regulation of atmospheric gases, and mediation of water flows (Ericksen and McSweeney, 1999; Doran and Parkin, 1996; Karlen and Stott, 1994; Larson and Pierce, 1991). Off-site environmental problems caused by cropping systems can often be linked to a compromised soil function as a result of poor soil management. Consequently, information on how cropping systems influence soil quality will allow agriculturists to design systems that are more environmentally sustainable (Karlen et al., 1994).

In the Western Corn Belt, monoculture corn and

M.A. Liebig, USDA-ARS, Northern Great Plains Research Laboratory, P.O. Box 459, Mandan, ND 58554; G.E. Varvel, J.W. Doran, and B.J. Wienhold, USDA-ARS, Soil and Water Conservation Research Unit, 120 Keim Hall, Dep. of Agronomy, University of Nebraska, Lincoln, NE 68583. The USDA-ARS is an equal opportunity/affirmative action employer and all agency services are available without discrimination. Received 28 March 2001. *Corresponding author (liebigm@ mandan.ars.usda.gov).

Published in Soil Sci. Soc. Am. J. 66:596-601 (2002). corn-soybean cropping systems predominate. The effect of these cropping systems on indicators of soil quality is only partially understood. Soil organic C has been shown to increase in monoculture corn where $\mathrm{N}$ fertilization is adequate and no-till is used (Studdert and Echeverria, 2000; Varvel, 1994; Havlin et al., 1990; Blevins et al., 1983). Conversely, a decline in soil organic C is well documented in cropping systems that include soybean in rotation (Studdert and Echeverria, 2000; Varvel, 1994; Karlen et al., 1994; Havlin et al., 1990; Franco-Vizcaíno, 1996). Observations of degraded soil physical conditions as reflected by decreased aggregate stability have been reported in both monoculture corn and corn-soybean cropping systems (Raimbault and Vyn, 1991; Hussain et al., 1988; Fahad et al., 1982), leading to concern regarding increased erosion susceptibility in these systems.

There is a need to identify corn-based cropping systems that do not jeopardize the capacity of the soil to function over the long-term. Cropping systems with extended rotations $(>2 \mathrm{yr})$ and multiple crops offer the potential to meet this need, but information on how they impact soil properties is scarce. In this study, we sought to determine the effect of four crop sequences (monoculture corn, corn-soybean, and two 4-yr sequences) and their interaction with three levels of $\mathrm{N}$ fertilization on soil properties for a long-term cropping system experiment in the Western Corn Belt.

\section{MATERIALS AND METHODS}

\section{Site Description}

The research site is located on the Agronomy Farm at the University of Nebraska Agricultural Research and Development Center $\sim 6 \mathrm{~km}$ south of Mead, NE in Saunders County $\left(41^{\circ} 10^{\prime} 12^{\prime \prime} \mathrm{N}\right.$ lat., $96^{\circ} 25^{\prime} 12^{\prime \prime} \mathrm{W}$ long.). The site is on Peoriaage loess with nearly level topography (0-3\% slope). The predominant soil at the site is Sharpsburg silty clay loam with an average particle-size distribution for the surface $30.5-\mathrm{cm}$ soil depth of $5 \%$ sand, $64 \%$ silt, and $31 \%$ clay.

A long-term cropping systems study comprised of seven crop sequences (three monoculture, two 2-yr, and two 4-yr rotations) with three rates of $\mathrm{N}$ fertilizer was established on the site in 1983 (Varvel, 1994). Corn-based cropping sequences included in the study were continuous corn, corn-soybean, corn-oat + clover $(80 \%$ sweet clover and $20 \%$ red clover)grain sorghum-soybean, and corn-soybean-grain sorghumoat + clover. The oat and clover intercrop represented a single year in each 4-yr sequence. Oat was harvested during the first

Abbreviations: CC, continuous corn; C-OCL-SG-SB, corn-oat + clover-grain sorghum-soybean; C-SB, corn-soybean; C-SB-SG-OCL, corn-boybean-grain sorghum-oat + clover; EC, electrical conductivity; HIGH, high N treatment; LOW, low N treatment; PMN, potentially mineralizable $\mathrm{N}$; POM, particulate organic matter; ZERO, zero $\mathrm{N}$ treatment. 
year while the clover was allowed to continue to grow into the fall. Crop sequence treatments were considered whole plots, and assigned to an area of 9 by $32 \mathrm{~m}$. Subplots ( 9 by $10 \mathrm{~m}$ ) were assigned within each whole plot, each differing by $\mathrm{N}$ application rate. Nitrogen rates were 0,90 , and $180 \mathrm{~kg}$ $\mathrm{N} \mathrm{ha}^{-1}$ for corn and grain sorghum and 0,34 , and $68 \mathrm{~kg} \mathrm{~N}$ $\mathrm{ha}^{-1}$ for soybean and oat + clover. Nitrogen was applied as a broadcast application of $\mathrm{NH}_{4} \mathrm{NO}_{3}$ in the spring of each year. Each phase of every crop sequence occurred every year and treatment combinations were replicated five times.

Cultural practices used in the study were similar to that of local producers. Crop residues from corn and grain sorghum were shredded in late fall. Clover was killed with a tandem disk in mid April when weather permitted. Tillage was conducted on all plots in the spring and usually consisted of disking, once or twice, 10 to $15 \mathrm{~cm}$ deep followed by harrowing just prior to planting. Details on other management practices with respect to planting, weed control, and harvesting are reported elsewhere (Varvel, 1994).

\section{Sampling Protocol}

Soil samples were collected in the spring of 1999 prior to tillage operations within each $\mathrm{N}$ fertilization treatment of the four corn-based crop sequences. For crop sequences with multiple crops, sampling was conducted in plots that were to be planted to corn. Samples were collected from the first three replicates of the experiment, where inherent soil conditions were most uniform. In each plot, six soil cores were collected from two depths, 0 to 7.6 and 0 to $30.5 \mathrm{~cm}$, using a $1.8-\mathrm{cm}$ (i.d.) step-down probe. Samples were composited by depth. To ensure composite samples were representative of each plot, two cores each were collected from the row, wheel-tracked interrow, and nonwheel-tracked interrow. Each composite sample was saved in a double-lined plastic bag, placed in cold storage at $5^{\circ} \mathrm{C}$, and analyzed for chemical and biological attributes within 1 wk of collection.

\section{Laboratory Evaluations}

Samples were processed by sieving through a 2.0 -mm sieve at field moisture content and subsampled for chemical and biological analyses. Electrical conductivity (EC) and soil $\mathrm{pH}$ were estimated from a 1:1 soil/water mixture (Dahnke and Whitney, 1988; Eckert, 1988). Soil $\mathrm{NO}_{3}-\mathrm{N}$ and $\mathrm{NH}_{4}-\mathrm{N}$ were estimated from 1:10 soil/ $\mathrm{KCl}(2 \mathrm{M})$ extracts using $\mathrm{Cd}$ reduction followed by a modified Griess-Ilosvay method and indophenol blue reaction (Mulvaney, 1996). Extractable P was determined by the Bray P-1 method as all soils had $\mathrm{pH}<7.0$ (Kuo, 1996). Particulate organic matter was determined by weight losson-ignition for the 0.053 - to 0.5 - and 0.5 - to $2.0-\mathrm{mm}$ size fractions (Cambardella et al., 2000). Total $\mathrm{C}$ and $\mathrm{N}$ were determined by dry combustion. Organic $\mathrm{C}$ was considered the same as total $\mathrm{C}$ as carbonates were not present in the depths sampled. Evaluations of extractable $\mathrm{P}$ and total $\mathrm{C}$ and $\mathrm{N}$ were conducted on air-dried soil ground with a roller mill to pass a 100-mesh sieve.

Potentially mineralizable $\mathrm{N}$ was estimated from the $\mathrm{NH}_{4}-\mathrm{N}$ accumulated after a $7-\mathrm{d}$ anaerobic incubation at $40^{\circ} \mathrm{C}$ (Bundy and Meisinger, 1994). Soil microbial biomass $\mathrm{C}$ was estimated by the microwave irradiation technique (Islam and Weil, 1998). Carbon dioxide content was determined by gas chromatography (Zibilske, 1994). Soil microbial biomass $\mathrm{N}$ was estimated from a $10-\mathrm{d}$ mineral $\mathrm{N}$ flush between irradiated and nonirradiated soil following the method of Shen et al. (1984).

Gravimetric data were converted to a volumetric basis by sampling depth using field measured soil bulk density (Blake and Hartge, 1986). Particle-size distribution was estimated using the hydrometer method (Gee and Bauder, 1986). Available water-holding capacity (i.e., percent volume of water retained between -33 and $-1500 \mathrm{kPa}$ ) was estimated from particle-size distribution, soil bulk density, and organic matter content (assuming 58\% of organic matter is composed of organic C) using a pedotransfer function (Gupta and Larson, 1979). All data were expressed on an oven-dry basis. Evaluations of samples from the 0 - to $7.6-\mathrm{cm}$ depth were limited to $\mathrm{EC}$, soil $\mathrm{pH}$, organic $\mathrm{C}$, total $\mathrm{N}$, and POM.

\section{Statistical Analysis}

Crop sequence and $\mathrm{N}$ fertilization effects on soil properties were evaluated using an appropriate split-plot model in PROC MIXED (Littell et al., 1996). Replication and its interaction with crop sequence were considered random effects. Treatment means were compared using least significant differences (LSD) at $P<0.05$.

Correlation analysis was used to identify relationships between soil properties from the 0- to 7.6- $\mathrm{cm}$ depth and longterm averages (1983-1998) of grain and stover yield, grain and stover $\mathrm{N}$ uptake, and residual soil $\mathrm{NO}_{3}-\mathrm{N}$. Yield and $\mathrm{N}$ uptake averages were specific to corn and limited to the plots where soil samples were collected in 1999. Significant correlations were identified using PROC REG (SAS Institute, 1990). Detailed background on data and methods for yield, yield components, and residual soil $\mathrm{NO}_{3}-\mathrm{N}$ is provided by Peterson and Varvel (1989a,b,c) and Varvel and Peterson (1990). Briefly, dry matter samples were collected each year when the crop was at physiological maturity. Representative plants from each plot were cut, weighed, dried, and threshed for grain. Ground subsamples of grain and stover were analyzed for total N (Kjeldahl prior to 1990, dry combustion thereafter). Averages for residual soil $\mathrm{NO}_{3}-\mathrm{N}$ reflected postharvest $\mathrm{NO}_{3-}$ $\mathrm{N}$ levels over the 0 - to $183-\mathrm{cm}$ depth (by summing the averages of $30.5-\mathrm{cm}$ depth increments to $183 \mathrm{~cm}$ ) taken at the end of each 4-yr rotation cycle (1986, 1990, 1994, and 1998).

\section{RESULTS AND DISCUSSION Cropping System Effects on Soil Properties}

Analysis of variance indicated $\mathrm{N}$ fertilization had a more pronounced effect on soil properties than crop sequence, with much of the effect limited to the surface 0 - to 7.6-cm depth where crop roots and residue were in greatest abundance, and management impacts of tillage and fertilization were most pronounced (Tables 1 and 2). At 0 to $30.5 \mathrm{~cm}, \mathrm{~N}$-rate affected soil $\mathrm{pH}$, soil $\mathrm{NO}_{3}-\mathrm{N}$, POM (0.5- to 2.0-mm fraction), and microbial biomass C and $\mathrm{N}$, whereas crop sequence affected only PMN (Table 1). At 0 - to 7.6-cm, EC, soil $\mathrm{pH}$, organic $\mathrm{C}$, total $\mathrm{N}$, POM (total and $0.5-2.0 \mathrm{~mm}$ fraction) were affected by N-rate, while crop sequence affected soil bulk density, soil $\mathrm{pH}$, and percentage of POM present as soil organic matter (Table 2). Significant interactions at 0 to 30.5 $\mathrm{cm}$ were observed for soil $\mathrm{pH}$ and microbial biomass $\mathrm{N}$, and for organic C and POM (total) at 0 to $7.6 \mathrm{~cm}$.

Soil bulk density and available water-holding capacity averaged $1.29 \mathrm{Mg} \mathrm{m}^{-3}$ (range $=1.28-1.32 \mathrm{Mg} \mathrm{m}^{-3}$ ) and $0.17 \mathrm{~m}^{3} \mathrm{~m}^{-3}$ (range $=0.16-0.18 \mathrm{~m}^{3} \mathrm{~m}^{-3}$ ), respectively, across all treatments over the 0 - to $30.5-\mathrm{cm}$ depth. At 0 to $7.6 \mathrm{~cm}$, soil bulk density averaged $1.26 \mathrm{Mg} \mathrm{m}^{-3}$ (range $=1.12-1.33 \mathrm{Mg} \mathrm{m}^{-3}$ ), and was significantly lower 
Table 1. Summary of $\boldsymbol{P}$ values for analysis of variance using Proc Mixed, showing main and interactive effects of crop sequence and $\mathrm{N}$ rate on soil properties at 0 to $30.5 \mathrm{~cm}$.

\begin{tabular}{|c|c|c|c|}
\hline \multirow[b]{2}{*}{ Soil property } & \multicolumn{3}{|c|}{ Source of variation } \\
\hline & Sequence & $\mathbf{N}$ rate & $\begin{array}{c}\text { Sequence } \\
\text { N rate }\end{array}$ \\
\hline Soil bulk density & 0.5398 & 0.8951 & 0.4141 \\
\hline Available water-holding capacity & 0.6457 & 0.6376 & 0.8426 \\
\hline Electrical conductivity & 0.4723 & 0.2311 & 0.5435 \\
\hline Soil pH & 0.1716 & $<0.0001$ & 0.0066 \\
\hline Soil $\mathrm{NO}_{3}-\mathbf{N}$ & 0.1368 & $<\mathbf{0 . 0 0 0 1}$ & 0.1464 \\
\hline Soil $\mathrm{NH}_{4}-\mathbf{N}$ & 0.7986 & 0.6044 & 0.3130 \\
\hline Extractable phosphorus & 0.3335 & 0.6595 & 0.9764 \\
\hline Organic $\mathbf{C}$ & 0.4580 & 0.8416 & 0.7022 \\
\hline Total N & 0.4254 & 0.9895 & 0.6571 \\
\hline Total POM & 0.3845 & 0.4679 & 0.8174 \\
\hline POM (0.5-2.0 mm) & 0.7635 & 0.0053 & 0.3205 \\
\hline POM (0.053-0.5 mm) & 0.0964 & 0.7305 & 0.7681 \\
\hline$\%$ POM as SOM & 0.6542 & 0.2308 & 0.4045 \\
\hline PMN (anaerobic) & 0.0371 & 0.4101 & 0.6052 \\
\hline Microbial biomass $\mathrm{C}$ & 0.4685 & 0.0468 & 0.8336 \\
\hline Microbial biomass $\mathbf{N}$ & 0.2409 & 0.0014 & 0.0434 \\
\hline
\end{tabular}

in the C-SB-SG-OCL crop sequence as compared with other sequences when averaged across N-rate (Table 3 ). The lower soil bulk density in this sequence was likely associated with improved soil physical conditions created by the oat and clover mixture the year prior to sampling. Inclusion of cover crops, such as the sweet and red clovers planted in the 4-yr crop sequences, are known to improve soil physical conditions, as reflected by lower soil bulk density, increased aggregate stability, and more rapid infiltration rates (Bruce et al., 1990; Raimbault and Vyn, 1991; Franco-Vizcaíno, 1996). In contrast, crop sequences coming out of soybean (C-SB and C-OCL-SG-SB) may have possessed a higher proportion of microaggregates $(<0.25 \mathrm{~mm})$ (Fahad et al., 1982; Martens, 2000), causing a decrease in interaggregate porosity and a proportional increase in soil bulk density.

Values for EC at both depths were nonsaline $(0.21$ and $0.20 \mathrm{dS} \mathrm{m}^{-1}$ for $0-30.5 \mathrm{~cm}$ and $0-7.6 \mathrm{~cm}$ depths, respectively), and therefore optimal for crop growth and soil microbial activity. Soil $\mathrm{pH}$ at 0 to 30.5 and 0 to $7.6 \mathrm{~cm}$ was affected by $\mathrm{N}$ rate (Table 4), with values decreasing with increasing $\mathrm{N}$ rate in all crop sequences except C-SB (Table 5). Soil acidification through nitrification of ammoniacal fertilizers is well documented (Bouman et al., 1995; Liebig and Doran, 1999; Gajda et al., 2000), and is likely responsible for the $\mathrm{pH}$ trends observed among N-rate treatments. Acidification by $\mathrm{N}$ fertilization may also account for the differences in soil
Table 2. Summary of $\boldsymbol{P}$ values for analysis of variance using Proc Mixed, showing main and interactive effects of crop sequence and $N$ rate on soil properties at 0 to $7.6 \mathrm{~cm}$.

\begin{tabular}{lrcc}
\hline & \multicolumn{3}{c}{ Source of variation } \\
\cline { 2 - 4 } Soil property & Sequence & N rate & Sequence $\times$ N rate \\
\hline Soil bulk density & $<\mathbf{0 . 0 0 0 1}$ & $\mathbf{0 . 4 3 8 1}$ & $\mathbf{0 . 4 8 8 1}$ \\
Electrical conductivity & $\mathbf{0 . 3 4 9 6}$ & $\mathbf{0 . 0 2 9 2}$ & $\mathbf{0 . 9 5 7 9}$ \\
Soil pH & $\mathbf{0 . 0 1 4 9}$ & $<\mathbf{0 . 0 0 0 1}$ & $\mathbf{0 . 0 9 6 5}$ \\
Organic C & $\mathbf{0 . 8 4 7 3}$ & $\mathbf{0 . 0 1 3 4}$ & $\mathbf{0 . 0 3 6 2}$ \\
Total N & $\mathbf{0 . 7 6 8 1}$ & $\mathbf{0 . 0 0 8 1}$ & $\mathbf{0 . 0 6 3 0}$ \\
Total POM & $\mathbf{0 . 0 8 3 9}$ & $\mathbf{0 . 0 2 2 3}$ & $\mathbf{0 . 0 1 5 4}$ \\
POM (0.5-2.0 $\mathbf{~ m m )}$ & $\mathbf{0 . 2 1 6 5}$ & $\mathbf{0 . 0 0 6 5}$ & $\mathbf{0 . 0 8 6 6}$ \\
POM (0.053-0.5 mm) & $\mathbf{0 . 1 1 0 1}$ & $\mathbf{0 . 3 7 3 9}$ & $\mathbf{0 . 0 5 7 3}$ \\
\% POM as SOM & $\mathbf{0 . 0 0 2 3}$ & $\mathbf{0 . 1 1 5 8}$ & $\mathbf{0 . 2 3 1 6}$ \\
\hline
\end{tabular}

$\mathrm{pH}$ among crop sequences at $7.6 \mathrm{~cm}$ (Table 3). Since $\mathrm{N}$ application rates during years with soybean and oat + clover are less than half than during years with corn or sorghum, the potential for acidification from nitrification was less in crop sequences where leguminous crops were included.

Soil $\mathrm{NO}_{3}-\mathrm{N}$ averaged $16 \mathrm{~kg} \mathrm{ha}^{-1}$ (range $=11-20 \mathrm{~kg}$ $\mathrm{ha}^{-1}$ ) for the 0 - to $30.5-\mathrm{cm}$ depth, and increased significantly with increasing $\mathrm{N}$ rate when averaged across crop sequence (Table 4). No differences were observed among treatments for soil $\mathrm{NH}_{4}-\mathrm{N}$, extractable $\mathrm{P}$, organic $\mathrm{C}$, and total $\mathrm{N}$ at 0 to $30.5 \mathrm{~cm}$. Overall averages for these parameters were $3 \mathrm{~kg} \mathrm{ha}^{-1}$ for soil $\mathrm{NH}_{4}-\mathrm{N}$ (range $=$ 1-7 kg ha ${ }^{-1}$ ), $11 \mathrm{~kg} \mathrm{ha}^{-1}$ for extractable $\mathrm{P}$ (range 8-15 $\mathrm{kg} \mathrm{ha}^{-1}$ ), $49.2 \mathrm{Mg} \mathrm{ha}^{-1}$ for organic C (range 41.5-56.7 $\mathrm{Mg} \mathrm{ha}^{-1}$ ), and $3.8 \mathrm{Mg} \mathrm{ha}^{-1}$ for total $\mathrm{N}$ (range 3.1-4.3 $\left.\mathrm{Mg} \mathrm{ha}^{-1}\right)$.

For the 0- to 7.6-cm depth, organic $\mathrm{C}$ and total $\mathrm{N}$ were significantly higher in the $\mathrm{HIGH} \mathrm{N}$-rate treatment as compared with the ZERO and LOW N-rate treatments when averaged over crop sequence (Table 4). The HIGH N-rate treatment possessed an average of 1.4 and $1.0 \mathrm{Mg} \mathrm{ha}^{-1}$ more organic $\mathrm{C}$ than the ZERO and LOW N-rate treatments, respectively. Among individual treatments, $\mathrm{CC}-\mathrm{HIGH}$ possessed the most organic $\mathrm{C}\left(17.8 \mathrm{Mg} \mathrm{ha}^{-1}\right)$ and CC-ZERO the least (13.5 $\mathrm{Mg} \mathrm{ha}^{-1}$ ), indicating the strong effect of $\mathrm{N}$ fertilization on organic $\mathrm{C}$ in monoculture corn. In contrast, organic $\mathrm{C}$ was essentially unchanged across $\mathrm{N}$ rates in $\mathrm{C}-\mathrm{SB}$ and both 4-yr crop sequences (Table 5).

Particulate organic matter was affected by $\mathrm{N}$ fertilization at both soil depths. Significantly more POM in the $0.5-$ to $2.0-\mathrm{mm}$ fraction was observed in the LOW and HIGH N-rate treatments as compared with the ZERO $\mathrm{N}$-rate treatment when averaged across crop sequence

Table 3. Mean values of soil properties affected by crop sequence.

\begin{tabular}{|c|c|c|c|c|c|}
\hline \multirow[b]{2}{*}{ Soil property } & \multicolumn{5}{|c|}{ Crop sequence $\dagger$} \\
\hline & $\mathbf{C C}$ & C-SB & C-OCL-SG-SB & C-SB-SG-OCL & LSD (0.05) \\
\hline \multicolumn{6}{|c|}{ 0-3.05 cm } \\
\hline PMN, kg ha ${ }^{-1}$ & 45 & 47 & $\overline{53}$ & 57 & 9 \\
\hline \multicolumn{6}{|c|}{$0-7.6 \mathrm{~cm}$} \\
\hline$D_{b}, \mathbf{M g ~ m}^{-3}$ & 1.31 & 1.31 & 1.26 & 1.17 & 0.06 \\
\hline $\mathbf{p H},-\log \left[\mathrm{H}^{+}\right]$ & 6.05 & 6.47 & 6.44 & 6.22 & 0.24 \\
\hline POM as SOM, \% & 13.4 & 13.7 & 14.5 & 17.1 & 1.9 \\
\hline
\end{tabular}

$\dagger$ CC, continuous corn; C-SB, corn-soybean; C-OCL-SG-SB, corn-oat + clover-sorghum-soybean; C-SB-SG-OCL, corn-soybean-sorghum-oat + clover $\$$ PMN, potentially mineralizable $\mathrm{N}$ (anaerobic); $D_{\mathrm{b}}$, soil bulk density; $\mathrm{pH}$, soil pH; POM, particulate organic matter; SOM, soil organic matter. 
Table 4. Mean values of soil properties affected by $\mathbf{N}$ fertilization.

\begin{tabular}{|c|c|c|c|c|}
\hline \multirow[b]{2}{*}{ Soil property $\$$} & \multicolumn{3}{|c|}{ N rate $\uparrow$} & \multirow[b]{2}{*}{ LSD (0.05) } \\
\hline & Zero & Low & High & \\
\hline \multicolumn{5}{|c|}{$0-30.5 \mathrm{~cm}$} \\
\hline $\mathbf{p H},-\log \left[\mathrm{H}^{+}\right]$ & 6.82 & 6.65 & 6.44 & 0.21 \\
\hline $\begin{array}{l}\mathrm{NO}_{3}-\mathrm{N}, \mathrm{kg} \mathrm{ha}^{-1} \\
\text { POM, } \mathrm{Mg} \mathrm{ha}^{-1}\end{array}$ & 14 & 16 & 19 & 2 \\
\hline $0.5-2.0 \mathrm{~mm}$ & 1.5 & 2.0 & 2.2 & 0.4 \\
\hline MBC, $\mathrm{kg} \mathrm{ha}^{-1}$ & 977 & 955 & 798 & 152 \\
\hline MBN, kg ha ${ }^{-1}$ & 114 & 108 & 91 & 11 \\
\hline \multicolumn{5}{|c|}{$0-7.6 \mathrm{~cm}$} \\
\hline $\mathbf{E C}, \mathbf{d S} \mathbf{m}^{-1}$ & 0.21 & 0.18 & 0.20 & 0.02 \\
\hline $\mathbf{p H},-\log \left[\mathrm{H}^{+}\right]$ & 6.57 & 6.42 & 5.90 & 0.17 \\
\hline SOC, $\mathrm{Mg} \mathrm{ha}^{-1}$ & 14.6 & 15.0 & 16.0 & 0.9 \\
\hline TN, $\mathbf{M g ~ h a}^{-1}$ & 1.3 & 1.3 & 1.4 & 0.1 \\
\hline \multicolumn{5}{|l|}{ POM, Mg ha } \\
\hline Total & 5.9 & 5.7 & 6.5 & 0.6 \\
\hline $0.5-2.0 \mathrm{~mm}$ & 1.7 & 1.5 & 2.1 & 0.3 \\
\hline
\end{tabular}

$\dagger$ Nitrogen rates were 0,90 , and $180 \mathrm{~kg} \mathrm{~N}^{\mathrm{Na}} \mathrm{h}^{-1}$ for corn and grain sorghum and 0,34 , and $68 \mathrm{~kg} \mathrm{~N} \mathrm{ha}^{-1}$ for soybean and oat + clover.

+ pH, soil pH; $\mathrm{NO}_{3}$-N, soil nitrate; POM, particulate organic matter; $\mathrm{MBC}$ microbial biomass $\mathrm{C}$; MBN, microbial biomass $\mathrm{N}$; EC, electrical conductivity; SOC, soil organic C; TN, total N.

at $0-$ to $30.5-\mathrm{cm}$. Total and $0.5-$ to $2.0-\mathrm{mm}$ POM fractions followed similar trends among treatments at 0 - to 7.6$\mathrm{cm}$, with levels significantly higher in the HIGH N-rate treatment as compared with the ZERO and LOW Nrate treatments (Table 4). In a trend similar to organic $\mathrm{C}$, total POM increased with increasing $\mathrm{N}$ rate in $\mathrm{CC}$. In $\mathrm{C}-\mathrm{SB}$, however, total $\mathrm{POM}$ varied little across $\mathrm{N}$ rates, and was highest at the ZERO $\mathrm{N}$ rate and lowest at the LOW N rate for both 4-yr crop sequences (Table 5). The lack of consistent response of POM within C-SB and the 4-yr sequences seems to suggest $\mathrm{N}$ fertilization is not a prerequisite to building up levels of this organic matter fraction.

Trends among treatments for organic $\mathrm{C}$, total $\mathrm{N}$, and POM confirmed results of a previous evaluation from the first $8 \mathrm{yr}$ of the experiment (Varvel, 1994). The effect of the HIGH $\mathrm{N}$ rate at the $0-$ to $7.6-\mathrm{cm}$ depth was particularly important, as it resulted in significantly higher levels of all three parameters when compared with the ZERO and LOW N-rate treatments. This effect was partially driven by the amount of crop residue returned to the soil, which from 1983 to 1998 averaged 4.5, 5.3, and 5.6 $\mathrm{Mg} \mathrm{ha}^{-1} \mathrm{yr}^{-1}$ across all crops in the ZERO, LOW, and HIGH N-rate treatments, respectively. Accordingly, the lack of a crop sequence effect on organic $\mathrm{C}$, total $\mathrm{N}$, and POM may also be explained based on the amount of crop residue returned to the soil, which over the same time span averaged 5.3, 4.8, 5.3, and $5.1 \mathrm{Mg} \mathrm{ha}^{-1} \mathrm{yr}^{-1}$ for CC, C-SB, C-OCL-SG$\mathrm{SB}$, and $\mathrm{C}-\mathrm{SB}-\mathrm{SG}-\mathrm{OCL}$, respectively.

Treatment effects on soil organic matter quality were apparent in this study. There was significantly more POM present as soil organic matter in the C-SB-SGOCL sequence $(17.1 \%)$ as compared with the other sequences (average $=13.9 \%$ ) for the 0 - to $7.6-\mathrm{cm}$ depth, indicating a potential improvement in the quality of organic matter by this crop sequence (Table 3 ). Particulate organic matter is considered to be a component of the intermediately labile soil organic matter pool (Cambardella and Elliott, 1992; Sikora et al., 1996), and
Table 5. Mean values for soil properties affected by interactive effects of crop sequence and $\mathbf{N}$ fertilization.

\begin{tabular}{|c|c|c|c|}
\hline \multirow[b]{2}{*}{ Crop sequence } & \multicolumn{3}{|c|}{$\mathbf{N}$ rate $\dagger$} \\
\hline & Zero & Low & High \\
\hline & $0-30.5 \mathrm{~cm}$ & & \\
\hline & \multicolumn{3}{|c|}{ Soil pH, $-\log \left[\mathbf{H}^{+}\right]$} \\
\hline $\mathbf{C C}$ & 6.89 & 6.56 & 6.05 \\
\hline C-SB & 6.86 & 6.59 & 6.71 \\
\hline C-OCL-SG-SB & 6.81 & 6.77 & 6.45 \\
\hline C-SB-SG-OCL & 6.73 & 6.68 & 6.55 \\
\hline \multicolumn{4}{|l|}{ LSD for interaction $=0.27$} \\
\hline & \multicolumn{3}{|c|}{ Microbial biomass N, $\mathbf{k g ~ h a}^{-1}$} \\
\hline $\mathbf{C C}$ & 108 & 95 & 75 \\
\hline C-SB & 98 & 103 & 110 \\
\hline C-OCL-SG-SB & 122 & 113 & 78 \\
\hline \multirow{2}{*}{\multicolumn{4}{|c|}{ LSD for interaction $=29$}} \\
\hline & & & \\
\hline \multicolumn{4}{|c|}{$0-7.6 \mathrm{~cm}$} \\
\hline & \multicolumn{3}{|c|}{ Soil organic $\mathrm{C}, \mathrm{Mg} \mathrm{ha}^{-1}$} \\
\hline $\mathrm{CC}$ & 13.5 & 14.6 & 17.8 \\
\hline C-SB & 14.1 & 14.7 & 15.1 \\
\hline C-OCL-SG-SB & 15.8 & 15.5 & 16.1 \\
\hline \multirow{3}{*}{$\begin{array}{l}\text { C-SB-SG-OCL } \\
\text { LSD for interaction }=3.2\end{array}$} & 14.9 & 15.2 & 14.9 \\
\hline & \multirow{2}{*}{\multicolumn{3}{|c|}{ Particulate organic matter, total, $\mathrm{Mg} \mathrm{ha}^{-1}$}} \\
\hline & & & \\
\hline CC & 4.2 & 5.6 & 6.8 \\
\hline C-SB & 5.5 & 5.7 & 5.7 \\
\hline C-OCL-SG-SB & 6.6 & 5.2 & 6.5 \\
\hline C-SB-SG-OCL & 7.3 & 6.3 & 7.1 \\
\hline
\end{tabular}

$\dagger$ Nitrogen rates were 0,90 , and $180 \mathrm{~kg} \mathrm{~N} \mathrm{ha}^{-1}$ for corn and grain sorghum and 0,34 , and $68 \mathrm{~kg} \mathrm{~N} \mathrm{ha}^{-1}$ for soybean and oat + clover.

$\$$ CC, continuous corn; C-SB, corn-soybean; C-OCL-SG-SB, corn-oat + clover-sorghum-soybean; C-SB-SG-OCL, corn-soybean-sorghumoat + clover.

is associated with nutrient mineralization and aggregate stability (Yakovchenko et al., 1998; Cambardella and Elliott, 1993). Results from this evaluation indicate inclusion of oat + clover in the C-SB-SG-OCL sequence enhanced this labile fraction over that observed in other crop sequences. The effect was apparently short-term, however, as the percentage of POM present as soil organic matter was lower in the other 4-yr crop sequence when soybean was the crop the year prior to sampling. Potentially mineralizable $\mathrm{N}$, also an indicator of soil organic matter quality (Drinkwater et al., 1996), was affected by crop sequence as well. The C-SB-SG-OCL sequence possessed significantly higher levels of PMN than the $\mathrm{CC}$ and $\mathrm{C}-\mathrm{SB}$ sequences when averaged across $\mathrm{N}$-rate, indicating greater $\mathrm{N}$ mineralization potential over the growing season (Table 3 ).

Microbial biomass $\mathrm{C}$ and $\mathrm{N}$ were significantly higher in the ZERO and LOW N-rate treatments as compared with the HIGH N-rate treatment when averaged across crop sequence (Table 4). Nitrogen fertilization may have decreased microbial biomass because of increased acidification from applied fertilizer. Negative effects of acidification on microbial biomass have been found by Kowalenko et al. (1978), where soil microbial activity (as indicated by $\mathrm{O}_{2}$ uptake) decreased with decreasing soil $\mathrm{pH}$ under controlled laboratory conditions. Alternatively, the higher levels of microbial biomass in the ZERO and LOW N-rate treatments may be an expression of an increased dependence on internal nutrient cycling. Cropping systems that rely upon internal sources 
Table 6. Correlation of soil properties at 0 to $7.6 \mathrm{~cm}$ with 16-yr averages of grain and stover yield, grain and stover $\mathrm{N}$ uptake, and residual soil $\mathrm{NO}_{3}-\mathrm{N}$. Crop parameters are specific for corn.

\begin{tabular}{|c|c|c|c|c|c|}
\hline $\begin{array}{l}\text { Soil properties, } \\
\text { 0-7.6 cm }\end{array}$ & Grain yield & $\begin{array}{l}\text { Stover } \\
\text { yield }\end{array}$ & $\begin{array}{l}\text { Grain N } \\
\text { uptake }\end{array}$ & $\begin{array}{c}\text { Stover N } \\
\text { uptake }\end{array}$ & $\begin{array}{c}\text { Residual soil } \\
\mathrm{NO}_{3}=\mathbf{N}, \mathbf{0}-183 \mathrm{~cm}\end{array}$ \\
\hline$D_{b} \dagger$ & 0.21 & 0.46 & 0.27 & 0.30 & 0.34 \\
\hline EC & -0.22 & -0.19 & -0.24 & -0.32 & -0.13 \\
\hline pH & -0.28 & -0.33 & -0.45 & $-0.72^{* *}$ & $-0.82 * *$ \\
\hline SOC & $0.69^{*}$ & $0.68 *$ & $0.66^{*}$ & $0.69 *$ & $\mathbf{0 . 8 2} * *$ \\
\hline TN & $0.61 *$ & $0.62 *$ & $0.62 *$ & $0.71 * *$ & $0.86 * *$ \\
\hline \multicolumn{6}{|l|}{ POM } \\
\hline Total & 0.34 & 0.19 & 0.28 & 0.28 & 0.30 \\
\hline $0.5-2.0 \mathrm{~mm}$ & 0.22 & 0.25 & 0.28 & 0.28 & 0.30 \\
\hline $0.053-0.5 \mathrm{~mm}$ & 0.35 & 0.12 & 0.23 & 0.15 & 0.17 \\
\hline$\%$ as SOM & 0.16 & 0.00 & 0.13 & 0.14 & 0.14 \\
\hline
\end{tabular}

* Indicates significance at $P<0.05$.

** Indicates significance at $\boldsymbol{P}<\mathbf{0 . 0 1}$.

$\dagger D_{\mathrm{b}}$, soil bulk density; EC, electrical conductivity; pH, soil pH; SOC, soil organic C; TN, total N; POM, particulate organic matter; SOM, soil organic matter.

of nutrients, such as those where no fertilizer is applied or at rates inadequate to meet crop needs, require microbial biomass to transform nutrients into plant-available forms for crop uptake.

No differences in microbial biomass were observed among crop sequences. However, microbial biomass $\mathrm{N}$ decreased with increasing N-rate in all crop sequences except $\mathrm{C}-\mathrm{SB}$, where it increased with increasing $\mathrm{N}$ rate (Table 5). No differences or trends were observed among treatments for ratios of microbial biomass $\mathrm{C}$ to organic C (data not shown).

\section{Correlations with Long-Term Averages of Crop and Soil Parameters}

Correlations between soil properties at $0-$ to $7.6-\mathrm{cm}$ and 16-yr averages of crop and soil parameters were significant in 12 of 45 possible associations (Table 6). Organic $\mathrm{C}$ and total $\mathrm{N}$ were correlated with all five parameters, while soil bulk density, EC, and POM (total, individual fractions, and percentage present as SOM) were correlated with none. Organic $\mathrm{C}$ and total $\mathrm{N}$ were positively correlated with all parameters. Significant negative correlations existed between residual soil $\mathrm{NO}_{3-}$ $\mathrm{N}$ and soil $\mathrm{pH}$, and stover $\mathrm{N}$ uptake and soil $\mathrm{pH}$, with the former association particularly strong $(r=-0.82$; $\left.r^{2}=0.67\right)$.

Positive correlations between grain and stover yield and soil organic $\mathrm{C}$ and total $\mathrm{N}$ confirmed the well-established association between biological productivity and soil organic matter and underscored its importance in supporting this critical soil function (Bauer and Black, 1994). Other significant correlations with organic $C$ and total $\mathrm{N}$ were driven presumably by $\mathrm{N}$ fertilization, with fertilization increasing grain and stover $\mathrm{N}$ uptake and residual soil $\mathrm{NO}_{3}-\mathrm{N}$. Interestingly, the positive correlation between soil organic $\mathrm{C}$ and residual soil $\mathrm{NO}_{3}-\mathrm{N}$ is reflective of a situation where two critical soil functions, biological productivity and nutrient cycling efficiency, were in direct opposition of one another based on the status of the properties representing each function.

The strong negative correlation between soil $\mathrm{pH}$ and residual soil $\mathrm{NO}_{3}-\mathrm{N}$ indicated the usefulness of $\mathrm{pH}$ measurements in obtaining a relative measure of N-use efficiency of cropping systems. The three cropping systems with the lowest surface soil $\mathrm{pH}(\mathrm{CC}, \mathrm{C}-\mathrm{SB}-\mathrm{SG}-\mathrm{OCL}$, C-OCL-SG-SB; all HIGH N-rate) were found to have the lowest $\mathrm{N}$-removal indices among corn-based crop sequences in a previous evaluation by Yamoah et al. (1998) (where N-removal indices were calculated as the ratio of $\mathrm{N}$ removed by crops to total soil $\mathrm{N}$ available to crops). This association is supporting evidence that soil acidification is an indicator of inefficient use of fertilizer N (Smith and Doran, 1996). The merit of this relationship possesses even greater importance on calcareous soils, where acidification can result in Closs to the atmosphere as $\mathrm{CO}_{2}$ (Suarez, 2000).

\section{SUMMARY AND CONCLUSION}

Sixteen years of crop sequence and $\mathrm{N}$ fertilization effects were found to moderately influence soil properties in a long-term cropping systems experiment in the Western Corn Belt. Nitrogen fertilization had a greater influence on soil properties than crop sequence, with much of the influence concentrated in the surface 7.6 $\mathrm{cm}$. Increased $\mathrm{N}$-rate resulted in higher organic $\mathrm{C}$, total $\mathrm{N}$, and POM, but lower microbial biomass and soil $\mathrm{pH}$. Among crop sequences, one 4-yr rotation (C-SB-SGOCL) possessed significantly lower soil bulk density and higher PMN and POM present as soil organic matter as compared with other crop sequences. Effects of crop sequence on soil bulk density and POM, however, may have been biased by the time of sampling within the rotation sequence.

For the treatments evaluated in this study, generalizations regarding two soil functions, biological productivity and nutrient cycling efficiency, can be made. The C-SB-SG-OCL crop sequence enhanced nutrient cycling efficiency as shown by its effect on PMN and POM present as soil organic matter. Nitrogen fertilization, on the other hand, resulted in a trade-off between its positive effect on biological productivity (as shown by increased organic $\mathrm{C}$, total $\mathrm{N}$, and $\mathrm{POM}$ ) and negative effect on nutrient cycling efficiency (as shown by decreased microbial biomass and soil $\mathrm{pH}$ ). While this conclusion is by no means new, it underscores the challenge agriculturalists face in efforts to develop productive and environmentally sound agricultural systems.

\section{ACKNOWLEDGMENTS}

We thank Tim Kettler, Susan Wagner, Tara Gilbert, and Susan Siragusa for conducting laboratory assessments. 


\section{REFERENCES}

Bauer, A., and A.L. Black. 1994. Quantification of the effect of soil organic matter content on soil productivity. Soil Sci. Soc. Am. J. 58:185-193.

Blake, G.R., and K.H. Hartge. 1986. Bulk density. p. 363-382. In A Klute (ed.) Methods of soil analysis. Part 1. 2nd ed. SSSA Book Series No. 5. SSSA and ASA, Madison, WI.

Blevins, R.L., G.W. Thomas, M.S. Smith, W.W. Frye, and P.L. Cornelius. 1983. Changes in soil properties after 10 years of continuous non-tilled and conventionally-tilled corn. Soil Tillage Res. 3:135146.

Bouman, O.T., D. Curtin, C.A. Campbell, V.O. Biederbeck, and H. Ukrainetz. 1995. Soil acidification from long-term use of anhydrous ammonia and urea. Soil Sci. Soc. Am. J. 59:1488-1494.

Bruce, R.R., G.W. Langdale, and L.T. West. 1990. Modification of soil characteristics of degraded soil surfaces by biomass input and tillage affecting soil water regime. p. 4-9. In Trans. 14th Int. Congress of Soil Science. International Society of Soil Science, Kyoto, Japan.

Bundy, L.G., and J.J. Meisinger. 1994. Nitrogen availability indices. p. 951-984. In R.W. Weaver et al. (ed.) Methods of soil analysis. Part 2. SSSA Book Series No. 5. SSSA and ASA, Madison, WI.

Cambardella, C.A., and E.T. Elliott. 1992. Particulate soil organic matter changes across a grassland cultivation sequence. Soil Sci. Soc. Am. J. 56:777-783.

Cambardella, C.A., and E.T. Elliott. 1993. Carbon and nitrogen distribution in aggregates from cultivated and native grassland soils. Soil Sci. Soc. Am. J. 57:1071-1076.

Cambardella, C.A., A.M. Gajda, J.W. Doran, B.J. Wienhold, and T.A. Kettler. 2000. Estimation of particulate and total organic matter by weight loss-on-ignition. In R. Lal et al. (ed.) Carbon Methods. CRC Press, Boca Raton, FL.

Dahnke, W.C., and D.A. Whitney. 1988. Measurement of soil salinity. p. 32-34. In Recommended chemical soil test procedures for the North Central Region. North Central Regional Publ. 221. North Dakota Agric. Exp. Stn. Bull. 499. North Dakota Agric. Exp. Stn., Fargo, ND

Doran, J.W., and T.B. Parkin. 1996. Quantitative indicators of soil quality: A minimum data set. p. 25-37. In J.W. Doran and A.J Jones (ed.) Methods for assessing soil quality. SSSA Spec. Publ. 49. SSSA, Madison, WI.

Drinkwater, L.E., C.A. Cambardella, J.D. Reeder, C.W. Rice. 1996 Potentially mineralizable nitrogen as an indicator of biologically active soil nitrogen. p. 217-229. In J.W. Doran and A.J. Jones (ed.) Methods for assessing soil quality. SSSA Spec. Publ. 49. SSSA, Madison, WI.

Eckert, D.J. 1988. Recommended $\mathrm{pH}$ and lime requirement tests. $\mathrm{p}$. 6-8. In Recommended chemical soil test procedures for the North Central Region. North Central Regional Publ. 221. North Dakota Agric. Exp. Stn. Bull. 499. North Dakota Agric. Exp. Stn., Fargo, ND.

Ericksen, P.J., and K. McSweeney. 1999. Fine-scale analysis of soil quality for various land uses and landforms in central Honduras. Am. J. Altern. Agric. 14(4):146-157.

Fahad, A.A., L.N. Mielke, A.D. Flowerday, and D. Swatzendruber 1982. Soil physical properties as affected by soybean and other cropping sequences. Soil Sci. Soc. Am. J. 46:377-381.

Franco-Vizcaíno, E. 1996. Soil quality in central Michigan: Rotations with high and low diversity of crops and manure. p. 327-335. In J.W. Doran and A.J. Jones (ed.) Methods for assessing soil quality. SSSA Spec. Publ. 49. SSSA, Madison, WI.

Gajda, A.M., J.W. Doran, T.A. Kettler, B.J. Wienhold, J.L. Pikul, and C.A. Cambardella. 2000. Soil quality evaluations of alternative and conventional management systems in the Great Plains. In $\mathrm{R}$. Lal et al. (ed.) Carbon Methods. CRC Press, Boca Raton, FL.

Gee, G.W., and J.W. Bauder. 1986. Particle-size analysis. p. 383-411. In A. Klute (ed.) Methods of soil analysis. Part 1. 2nd ed. SSSA Book Ser. No. 5. SSSA and ASA, Madison, WI.

Gupta, S.C., and W.E. Larson. 1979. Estimating soil water retention characteristics from particle size distribution, organic matter percent, and bulk density. Water Resour. Res. 15:1633-1635.

Havlin, J.L., D.E. Kissel, L.D. Maddux, M.M. Classen, and J.H. Long. 1990. Crop rotation and tillage effects on soil organic carbon and nitrogen. Soil Sci. Soc. Am. J. 54:448-452.

Hussain, S.K., L.N. Mielke, and J. Skopp. 1988. Detachment of soil as affected by fertility management and crop rotations. Soil Sci. Soc. Am. J. 52:1463-1468.

Islam, K.R., and R.R. Weil. 1998. Microwave irradiation of soil for routine measurement of microbial biomass carbon. Biol. Fertil. Soils. 27:408-416.

Karlen, D.L., and D.E. Stott. 1994. A framework for evaluating physical and chemical indicators of soil quality. p. 53-72. In J.W. Doran et al. (ed.) Defining soil quality for a sustainable environment. SSSA Spec. Publ. 35. SSSA, Madison, WI.

Karlen, D.L., G.E. Varvel, D.G. Bullock, and R.M. Cruse. 1994. Crop rotations for the 21st century. p. 1-45. In D.L. Sparks (ed.) Advances in Agronomy. Vol. 54. Academic Press, San Diego.

Karlen, D.L., M.J. Mausbach, J.W. Doran, R.G. Cline, R.F. Harris, and G.E. Shuman. 1997. Soil quality: A concept, definition, and framework for evaluation (A guest editorial). Soil Sci. Soc. Am. J. 61:4-10.

Kowalenko, C.G., K.C. Ivarson, and D.R. Cameron. 1978. Effect of moisture content, temperature and nitrogen fertilization on carbon dioxide evolution from field soils. Soil Biol. Biochem. 10:417-423.

Kuo, S. 1996. Phosphorus. p. 869-919. In D.L. Sparks (ed.) Methods of soil analysis. Part 3. SSSA Book Series No. 5. SSSA and ASA, Madison, WI.

Larson, W.E., and F.J. Pierce. 1991. Conservation and enhancement of soil quality. In Evaluation for sustainable land management in the developing world. Vol. 2. IBSRAM Proc. 12(2). Bangkok, Thailand. Int. Board for Soil Res. and Management.

Liebig, M.A., and J.W. Doran. 1999. Impact of organic production practices on soil quality indicators. J. Environ. Qual. 28:1601-1609.

Littell, R.C., G.A. Milliken, W.W. Stroup, and R.D. Wolfinger. 1996 SAS system for mixed models. SAS Inst., Inc., Cary, NC.

Martens, D.A. 2000. Management and crop residue influence soil aggregate stability. J. Environ. Qual. 29:723-727.

Mulvaney, R.L. 1996. Nitrogen - Inorganic forms. p. 1123-1184. In D.L. Sparks (ed.) Methods of soil analysis. Part 3. SSSA Book Series No. 5. SSSA and ASA, Madison, WI.

Peterson, T.A., and G.E. Varvel. 1989a. Crop yield as affected by rotation and nitrogen rate: I. Soybean. Agron. J. 81:727-731.

Peterson, T.A., and G.E. Varvel. 1989b. Crop yield as affected by rotation and nitrogen rate: II. Sorghum. Agron. J. 81:731-734.

Peterson, T.A., and G.E. Varvel. 1989c. Crop yield as affected by rotation and nitrogen rate: III. Corn. Agron. J. 81:735-738.

Raimbault, B.A., and T.J. Vyn. 1991. Crop rotation and tillage effects on corn growth and soil structural stability. Agron. J. 83:979-985.

SAS Institute. 1990. SAS/STAT user's guide. Version 6.0, 4th ed. Vol. 2. SAS Inst., Cary, NC.

Shen, S.M., G. Pruden, and D.S. Jenkinson. 1984. Mineralization and immobilization of nitrogen in fumigated soil and the measuremen of microbial biomass nitrogen. Soil Biol. Biochem. 16:437-444.

Sikora, L.J., V. Yakovchenko, C.A. Cambardella, and J.W. Doran. 1996. Assessing soil quality by testing organic matter. p. 41-50. In F.R. Magdoff et al. (ed.) Soil organic matter: Analysis and interpretation. SSSA Spec. Publ. No. 46. SSSA, Madison, WI.

Smith, J.L., and J.W. Doran. 1996. Measurement and use of pH and electrical conductivity for soil quality analysis. p. 169-185. In J.W. Doran and A.J. Jones (ed.) Methods for assessing soil quality. Soil Sci. Soc. Am. Spec. Publ. 49. SSSA, Madison, WI.

Studdert, G.A., and H.E. Echeverria. 2000. Crop rotations and nitrogen fertilization to manage soil organic carbon dynamics. Soil Sci. Soc. Am. J. 64:1496-1503.

Suarez, D.L. 2000. Impact of agriculture on $\mathrm{CO}_{2}$ as affected by changes in inorganic carbon. p. 257-272. In R. Lal et al. (ed.) Global climate change and pedogenic carbonates. CRC Press, Boca Raton, FL.

Varvel, G.E. 1994. Rotation and nitrogen fertilization effects on changes in soil carbon and nitrogen. Agron. J. 86:319-325.

Varvel, G.E., and T.A. Peterson. 1990. Residual soil nitrogen as affected by continuous two-year and four-year rotations. Agron. J. 82:958-962.

Yakovchenko, V.P., L.J. Sikora, and P.D. Millner. 1998. Carbon and nitrogen mineralization of added particulate and macroorganic matter. Soil Biol. Biochem. 30:2139-2146.

Yamoah, C.F., G.E. Varvel, W.J. Waltman, and C.A. Francis. 1998. Long-term nitrogen use and nitrogen-removal index in continuous crops and rotations. Field Crops Res. 57:15-27.

Zibilske, L.M. 1994. Carbon mineralization. p. 835-863. In R.W. Weaver et al. (ed.) Methods of soil analysis. Part 2. SSSA Book Series No. 5. SSSA and ASA, Madison, WI. 